\author{
Struvite 결정화에 의한 축산폐수로 부터 질소· I 자원의 재생 \\ 조원실 · 윤성준 · 라창식 \\ 강원대학교 동물자원과학대학 동물자원학부
}

\title{
Recovery of $\mathrm{N}$ and $\mathrm{P}$ Resources from Animal Wastewater by Struvite Crystallization
}

\author{
W. S. Jo, S. J. Yoon and C. S. Ra \\ Division of Animal Resource Science, Kangwon National University
}

\begin{abstract}
Operational parameters for struvite crystallization, as a process to recover nitrogen and phosphorus resources from animal wastewater, were studied in this research. Crystallization distinctive of $\mathrm{NH}_{4}-\mathrm{N}$ and $\mathrm{PO}_{4}{ }^{3-}$ in accordance to chemical sources, influent $\mathrm{pH}$, aeration and stirring was examined using $2 \mathrm{~L}$ of working volume of struvite reactor. Also, to find an effective treatment process combining with electrolysis method, removal characteristics of $\mathrm{NH}_{4}-\mathrm{N}$ and $\mathrm{PO}_{4}{ }^{3-}$ in 6 different processes was tested. As chemical sources for the derivation of struvite formation, $\mathrm{MgSO}_{4}$ and $\mathrm{MgCl}_{2}$ were superior to $\mathrm{CaCO}_{3}$ and $\mathrm{CaCl}_{2}$. From experiment which was conducted to know the effects of aeration and stirring on struvite formation, it was revealed that aeration stimulated the crystallization reaction by inducing faster $\mathrm{pH}$ increase. While $90 \%$ of $\mathrm{P}$ removal was achieved within 1 hour under aeration, 14 hours was consumed under stirring condition. Struvite formation under aeration was affected by influent $\mathrm{pH}$. No crystallization was observed at $\mathrm{pH} 5$ level, but active crystallization reaction was induced over $\mathrm{pH}$ 6.0. 95\% of $\mathrm{P}$ removal by struvite formation at $\mathrm{pH} 6,7$ and 9 was achieved within $3 \mathrm{~h}, 2 \mathrm{~h}$ and $10 \mathrm{~min}$., respectively. However, over $\mathrm{pH} 10$, operational problem due to excessive foam formation occurred, and blunting of crystallization reaction was observed at $\mathrm{pH} 11$. When consider the $\mathrm{pH}$ range of animal wastewater, $\mathrm{pH} 7$ to 9 , efficient struvite formation could be achieved by simple aeration, without any chemical usage for $\mathrm{pH}$ adjustment. Among tested processes, the treatment process which electrolyzing the supernatant from struvite reactor, providing air to both reactors, showed best pollutant removal efficiencies. In this combined process, the removal efficiencies of $\mathrm{NH}_{4}-\mathrm{N}$ and $\mathrm{PO}_{4}{ }^{3-}$ was $86 \%$ and $98 \%$, respectively, and $92.4 \%$ of color removal was obtained.
\end{abstract}

(Key words : Struvite, Crystallization, Electrolysis, Swine wastewater)

$\begin{array}{cl}\text { I 서 론 } & \text { 어 처리 없이 방류하거나 혹은 토양에 과비시 } \\ & \text { 심각한 환경적 문제를 야기시킬 수 있기 때문 } \\ \text { 가축사육이 집단화 혹은 대규모화됨에 따라 } & \text { 이다. 이에 토양에 살포되는 가축분뇨의 양은 } \\ \text { 가축분뇨의 저장과 처리는 큰 문제가 되고있 } & \text { 법률적으로 제한하고 있으며 2000년 축산폐수 } \\ \text { 다. 이는 축산분뇨 및 폐수는 부영양화의 주원 } & \text { 방류기준에 질소와 인이 포함되고 그 규제가 } \\ \text { 인 물질인 질소와 인을 다량으로 함유하고 있 } & \text { 점점 강화될 것으로 보여 축산농가에 더욱 큰 }\end{array}$

Corresponding author : C. S. Ra, Division of Animal Resource Science, Kangwon National University, Chunchon, 200-701, Korea. Tel : 033)250-8618, Fax : 033)244-2433, E-mail : changsix@kangwon.ac.kr 
부담감으로 다가올 것으로 판단된다.

현재 국내에서는 가축분뇨를 처리하기 위해 자원화 방법으로는 고형퇴비화와 액비화 방법 이 널리 이용되고 있으며 뇨. 수의 정화 방 법으로는 생물학적 처리방법이 주로 이용되고 있다. 비료자원으로의 재활용에 있어서 한국 축산농가 현실에서는 발생하는 분뇨를 살포할 수 있는 충분한 토양을 확보하고 있는 농가가 거의 없기 때문에 부숙화 방법 등을 사용하여 안전한 고품질의 유기비료로 만든 후에 멀리 떨어진 다른 지역의 농경지로 운송하여 사용하 거나 혹은 판매하는 것이 효율적이라 할 수 있 다. 그러나 고형퇴비화의 경우 수분 함량이 높 은 축산분뇨를 효율적으로 부숙시키기 위해 다 량의 부형물질을 사용하여야 하기 때문에 처리 비용이 많이 소요됨은 물론 처리량도 많아지게 되고, 액비의 경우에도 그 성상으로 인해 취급 및 운반이 어렵고 살포를 위해 액비 살포차가 필요하여 다른 농경지로의 운송 및 이용에 많 은 경비와 노력이 요구될 뿐만 아니라 농작물 이 자라고있는 동안에는 지속하여 사용할 수 없는 등의 단점이 축산분뇨의 비료자원화에 큰 걸림돌로 작용하고 있다. 따라서 가축분뇨내에 고농도로 함유되어 있는 유기비료 성분들을 농 축시켜 분말화하거나 혹은 고형화한다면 다른 지역으로의 운송도 매우 용이할 뿐만 아니라 화학 비료처럼 연중 사용이 가능하고 또한 농 지에 살포되는 양이 매우 적어지기 때문에 노 동력 감소효과도 있을 것으로 판단된다. 네덜 란드의 경우에는 축산분뇨로부터 인을 회수하 여 재활용하기 위해 분뇨를 완전 소각한 후 그 재를 회수하여 사용하고 있다(Willem 등, 2001).

현재 한국이나 일본 등 많은 나라에서는 인 산업에 필요한 원료물질 대부분을 외국에서 수 입하고 있으며 궁극적으로는 가까운 장래에 지 구상에서 인이 고갈될 우려가 있어 대체 인 자 원 확보가 시급하다(Moriyama 등, 2001; Frank 등, 2001). 이러한 이유로 현재 네덜란드와 홀 란드, 프랑스, 일본, 스웨덴, 독일 등 많은 나라 에서는 하수내의 인을 회수하여 재활용하기 위 한 시스템을 개발. |용하고 있다. 예로 홀란 드에서는 폐수내의 인을 재생하여 인 산업에서
재활용하는 방법의 실용화를 통해 인 채광을 약 $20 \%$ 정도 줄이고자 노력을 하고 있으며 (Frank 등, 2001), 가까운 일본에서는 하수내 인 을 회수하는 공정이 실규모로 운전되고 있고 (Moriyama 등, 2001; Ueno 등, 2001) 이 공정들 에서 생산 - |수된 인이 고가의 비료자원으로 시판되고 있다. 또한 생물학적 축산폐수 처리 후 인을 회수하는 공정과 회수된 인의 재활용 방안 등에 대해서도 많은 연구가 진행되고 있 다(Schulze- Rettmer 등, 2001; Daumer 등, 2001).

축산분뇨 및 폐수의 액비화 및 고형 퇴비화 에서의 문제점과 방류수질 강화로 인한 축산 농가 부담증가 문제, 지구상의 인 고갈문제를 동시에 해결할 수 있는 방법은 가축분뇨나 폐 수내에 고농도로 존재하는 인과 질소를 제 거 . 수하는 것이라 할 수 있다. 화학 적 방법 중에 하나인 struvite 결정화 방법은 $\mathrm{MgNH}_{4} \mathrm{PO}_{4} \cdot \mathrm{H}_{2} \mathrm{O}$ 결정이나(James D. 등, 2002) $\mathrm{CaNH}_{4} \mathrm{PO}_{4} \cdot \mathrm{H}_{2} \mathrm{O}$ 로 결정시켜 질소와 인을 재 생 · · |수하는 방법으로서(이원희, 2000) 많은 연구자들에 의해 연구되어 온 결과 struvite 형성에 있어서의 암모니아와 인 그리고 마그네 슘 혹은 칼슘의 결합비, 결정화 시 알칼리도의 변화 및 적정 $\mathrm{pH}$ 등에 관한 결정화 인자와 결 정특성 등이 많이 밝혀졌다. Struvite 결정화에 있어서 암모니아와 마그네슘, 그리고 인의 몰 비율은 1:1:1이며(김만수 등, 2002; 원성연 등, 2000; 이원희, 2000; 임찬섭 등, 2000) struvite 의 비중이 1.7 이고, 열을 가하면 분해되고 물에 대한 용해도가 낮을 뿐 아니라 산성용액에서는 높은 용해성을 가지나 알칼리성 용액에서는 불 용성이라고 보고되고 있다(원성연 등, 2000). 또한, struvite는 상업적 가치도 크기 때문에 인 과 질소제거 목적은 물론 그 산물을 판매하여 수익을 얻을 수 있는 것으로 보고되고 있다 (Jaffer 등, 2001). 그러나 이러한 연구결과들은 대부분이 하수를 대상으로 수행된 것으로서 축 산폐수와 같은 성상을 지닌 폐수에서의 struvite 결정화 인자에 대한 연구는 아직 부족한 실정 이다.

축산폐수는 처리 후에도 악취를 유발할 수 있으며 병원성 세균의 번식 및 색도를 가지는 
고분자 물질을 다량 함유하고 있어 이러한 문 제점을 해결하지 않고 하천이나 호소로 유입될 시 색도의 증가로 광 투시도가 저하되어 자정 능력의 저하를 불러일으킬 뿐 아니라 병원성 세균의 번식으로 어류와 수생 생물에 악영향을 줄 수 있다. 이러한 문제들을 해결하기 위해 최근들어 고속 전자빔 법, 광 촉매 산화 법, 전 기 화학적 처리 법 등 많은 색도 제거 방법들 이 이용되고 있으며, 병원성 세균을 사멸하기 위해 오존처리나 전기분해에 의한 소독 등이 많이 쓰이고 있다. 특히 전기화학을 이용한 전 기분해 방법은 색도와 병원성 세균의 사멸을 동시에 가지고 올뿐만 아니라 타 공정에 비해 부대비용이 적게 들고 설치가 용이하며 처리 장치의 크기에 비해 처리효율이 뛰어나고 반응 의 제어가 용이한 장점을 가지고 있다(진은정 등, 2000). 또한 전기분해 방법은 축산폐수와 같은 고분자의 난분해성 유기물질의 독성을 파 괴하고 병원성 세균의 살균 효과가 뛰어난 것 으로 보고되고 있다(길대수 등, 2000).

전기화학반응은 전기분해와 전기응집으로 구 분될 수 있고, 이런 모든 반응들은 폐수 내에 존재하는 전자의 움직임에 의해 일어난다. 식 $-1 \sim 4$ 는 전기화학 반응에 의한 오염물질 제거기 전을 나타낸 것으로 전기화학반응은 전하를 가 진 오염물질을 양극에 흡착 후 접촉면에서 직 접 오염물질을 파괴시켜 제거하는 직접산화법 과 하이포염소산, 펜톤물질, 산화된 메라닌 등 의 중간 생성물에 의해 오염물질을 제거하는 간접 산화 법으로 다시 구분되며, 전기응집은 전극판에서 이온이 용출되어 폐수중의 오염물 질과 응집 · 착하여 수소와 염소가스에 의해 부상되거나 침전되어 물과 분리한다(Chiang 등, 1995). 직접산화 반응은 식-1과 같이 물의 전기 분해에 의해 생성되는 $\mathrm{OH}^{-}$라디칼에 의해 오 염물질을 산화하여 파괴하며, 간접산화 반응은 식-2, 3, 4와 같이 염소이온이 염소분자로 되어 물과 결합 분해되면서 $\mathrm{OCl}^{-}$을 생성하게 됨으로 써 오염물질을 산화하여 파괴하고 직접산화 반 응보다 간접산화 반응이 훨씬 오염물질 산화에 도움이 된다고 보고되고 있다(조주식 등, 2000: Lin 등, 1996).

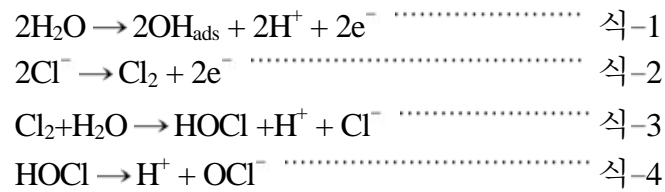

본 연구에서는 돈사폐수내의 질소와 인을 재 생 - |수하기 위한 struvite 결정화방법의 운전 인자와 그 결정체 형태를 파악하고 아울러 폐 수처리측면에서 효율적인 struvite 결정화법과 전기분해법의 연계공정을 찾고자 하였다.

\section{ㅍ 실험 재료 및 방법}

\section{1. 실험장치}

\section{(1) 결정화 실험 장치}

암모니아와 인의 결정화시 주입원의 종류, $\mathrm{pH}$, 교반과 폭기 등의 영향인자를 알아보기 위 하여 총용적 2.3L, 유효용적 $2 \mathrm{~L}$ 의 반응조를 이 용하였으며(Fig. 1), 포기시 공기의 주입량은 $2 \mathrm{~L} / \mathrm{min}$.이었고 교반은 200rpm으로 고정하였다.

\section{(2) 전기분해 장치}

실험에 쓰인 전기 분해조는 batch mode로 총 용적 $1.6 \mathrm{~L}$ 의 원통형 플라스틱을 사용하여 유효 용적 $1 \mathrm{~L}$ 로 실험하였다. 전력공급은 최대 12 Voltage, 250Ampere의 D.C power supply를 사용 하였으며, 전압을 12 Voltage로 고정하고 필요 한 전류밀도에 따라 전류를 공급하였다. 양극 판은 염소가스 및 극판의 전자방출로 인한 극 판의 부식을 막기 위해 티타늄(Ti)에 이리듐 $\left(\mathrm{IrO}_{2}\right)$ 을 전착한 불용성 극판(DSA)을 사용하였 고 음극판은 스테인레스 스틸판을 사용하였다. 극판의 두께는 $0.1 \mathrm{~cm}$ 로 하였으며 극판의 크기 는 $20 \mathrm{~cm} \times 2 \mathrm{~cm}$ 로 하였다. 전극판의 간격은 $1.5 \mathrm{~cm}$ 을 유지하여 실험하였다.

\section{2. 결정화 운전인자 파악 시험}

본 실험에 사용한 폐수로는 돈사폐수가 이용 되었다(Table 1), 돈사폐수의 평균 $\mathrm{pH}$ 는 7.85로 

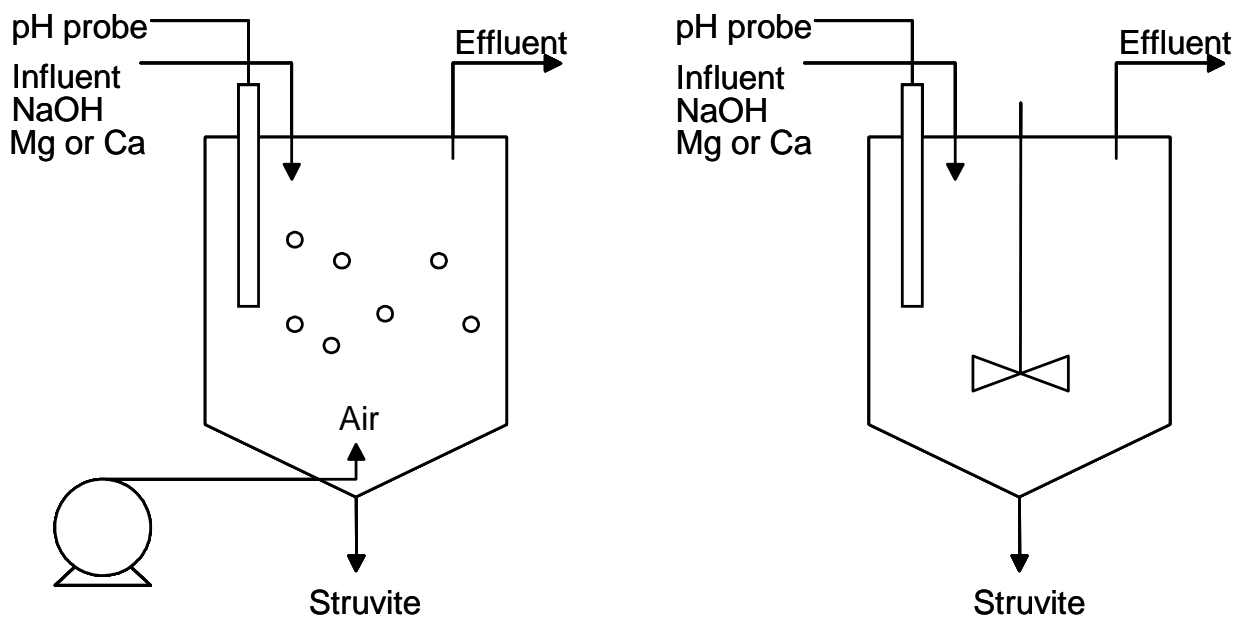

Fig. 1. Schematic of struvite process(aeration and mixing).

Table 1. Characteristics of swine wastewater

\begin{tabular}{lrrrr}
\hline & Means & \multicolumn{1}{c}{ Min. } & Max. & St-dev \\
\hline \hline $\mathrm{pH}$ & 7.85 & 7.65 & 8.40 & \\
$\mathrm{PO}_{4}{ }^{3-}(\mathrm{mg} / \mathrm{L})$ & 87.6 & 54.0 & 120.2 & 13.7 \\
$\mathrm{NH}_{4}{ }^{+}(\mathrm{mg} / \mathrm{L})$ & $2,470.0$ & $1,981.0$ & $2,114.3$ & 134.2 \\
$\mathrm{NOx}^{-}(\mathrm{mg} / \mathrm{L})$ & 0.5 & 0.0 & 1.4 & 0.45 \\
\hline
\end{tabular}

약알카리성이었으며, 암모니아와 인의 평균 농 도는 각 각 $2,470 \mathrm{mg} / \mathrm{L}$ 와 $87.6 \mathrm{mg} / \mathrm{L}$ 이었다. 주입 원에 따른 결정화 특성을 파악하기 위해 2가 양이온인 $\mathrm{Mg}^{2+}$ 과 $\mathrm{Ca}^{2+}$ 을 사용하였으며 $\mathrm{Mg}^{2+}$ 이 온으로는 $\mathrm{MgSO}_{4}, \mathrm{MgCl}_{2}, \mathrm{Mg}(\mathrm{OH})_{2}$ 를, $\mathrm{Ca}^{2+}$ 이온 으로는 $\mathrm{CaCO}_{3}, \mathrm{CaCl}_{2}$ 을 각각 $\mathrm{PO}_{4}{ }^{3-} 1.3 \mathrm{~mole}$ 기 준으로 하여 시험하였다.

$\mathrm{pH}$ 영향 파악 실험에서는 $\mathrm{HCl}$ 과 $\mathrm{NaOH}$ 를 사 용하여 $\mathrm{pH}$ 를 5 1 로 조정하고 $\mathrm{MgSO}_{4}$ 를 $\mathrm{PO}_{4}^{3-}$

기준 1.3 mole 주입하여 실험을 실시하였다. 교
반과 폭기에 따른 실험에서는 $\mathrm{MgSO}_{4}$ 를 $\mathrm{pH}$ 조절 없이 $\mathrm{PO}_{4}^{3-}$ 기준 $1.3 \mathrm{~mole}$ 주입하여 시험하였다.

\section{Struvite와 전기분해 연계공정 도출시험}

축산폐수에 있어서 가장 좋은 제거효율을 보 이는 struvite 결정화와 전기분해법의 연계공정 을 찾고자 Table 2와 같은 6가지 연계공정에서 의 $\mathrm{NH}_{4}-\mathrm{N}$ 과 $\mathrm{PO}_{4}^{3-}$ 의 제거특성을 분석하였다. 첫번째 공정은 유입수의 $\mathrm{pH}$ 를 조절한 후 struvite 결정화 방법을 거치고 상등액을 전기분 해 하는 공정이며, 두 번째 공정은 유입수 $\mathrm{pH}$ 조절 없이 struvite 반응을 거친 후 상등액을 전 기분해 하는 공정이고, 세 번째 공정은 먼저 전기분해 한후 struvite 반응을 거치고 그 후에 포기를 수행하는 공정이고, 네 번째 공정은 struvite 반응 후에 상등액을 전기분해한다음 포

Table 2. Operation methods

\begin{tabular}{|c|c|c|c|c|c|}
\hline Operation methods & A & $\rightarrow$ & B & $\rightarrow$ & $\mathrm{C}$ \\
\hline Run I & $\mathrm{pH}$ control & & struvite & & electrolysis \\
\hline Run $\Pi$ & struvite & & electrolysis & & \\
\hline Run III & electrolysis & & struvite & & aeration \\
\hline Run IV & struvite & & electrolysis & & aeration \\
\hline Run $\mathrm{V}$ & struvite & & electrolysis+aeration & & \\
\hline Run VI & struvite+aeration & & electrolysis+aeration & & \\
\hline
\end{tabular}


기시키는 공정이며, 다섯 번째 공정은 struvite 반응 후에 전기분해와 포기를 동시에 수행하는 공정이고, 여섯 번째 공정은 포기조건에서 struvite 반응 후에 전기분해와 포기를 함께 수 행하는 공정이다. 첫 번째 공정에서만 유입수 의 $\mathrm{pH}$ 가 9.0으로 조절되었으며 struvite 반응을 위한 $\mathrm{Mg}$ 주입원으로는 $\mathrm{MgCl}_{2}$ 가 사용되었고 전 기분해는 전해질 첨가 없이 양극판과 음극판 면적의 합이 $60 \mathrm{~cm}^{2} / \mathrm{L}$ 조건에서 수행하였다.

\section{4. 분석방법}

채취된 sample은 filter paper(Watman, N0.1541. 110 )를 이용하여 필터 후 분석하였다. $\mathrm{NH}_{4}-\mathrm{N}$, $\mathrm{PO}_{4}$-P의 분석은 자동수질 분석기(Zellweger: LACHAT, QuikChem 8000)을 사용하였으며, 색 도는 UV-visible spectrophotometer를 이용하여 $400 \mathrm{~nm}$ 에서 absorbance를 측정하였고, 측정된 값 을 수질공정시험법의 색도 값에 따라 색도를 측정하였다.

\section{III 결과 및 고찰}

\section{Struvite 결정화 인자}

$\mathrm{Mg}$ 혹은 $\mathrm{Ca}$ 주입원에 따른 struvite 결정화 특성을 파악하기 위하여 $\mathrm{Mg}(\mathrm{OH})_{2}, \mathrm{MgSO}_{4}$, $\mathrm{MgCl}_{2}, \mathrm{CaCO}_{3}, \mathrm{CaCl}_{2}$ 를 폐수내 인 기준 1.3 몰 비율로 첨가하여 $\mathrm{pH}$ 변화 및 인, 질소의 제거 특성을 분석하였다(Fig. 2). $\mathrm{pH}$ 가 8.3인 폐수에 $\mathrm{Mg}(\mathrm{OH})_{2}, \mathrm{MgSO}_{4}, \mathrm{MgCl}_{2}, \mathrm{CaCO}_{3}, \mathrm{CaCl}_{2}$ 가 첨가 됨에 따라 $\mathrm{pH}$ 가 약 7.7 수준으로 감소하면서 $\mathrm{PO}_{4}^{3-}$ 제거효율은 각각 $49.4 \%, 40.6 \%, 49.1 \%$, $38.1 \%, 37.3 \%, \mathrm{NH}_{4}-\mathrm{N}$ 의 제거효율은 각각 $2.5 \%$, $3.5 \%, 2.5 \%, 0 \%, 0.5 \%$ 로 $\mathrm{Mg}$ 를 주입원으로 사 용하는 것이 struvite 결정화 반응이 빠르게 일 어남을 알 수 있었다. $\mathrm{Mg}$ 원과 $\mathrm{Ca}$ 원의 주입 직 후 $\mathrm{pH}$ 가 낮아진 것은 주입된 시약과 폐수내 의 물질들이 반응하여 알칼리도를 소모했다 고 보여지며 마그네슘원의 첨가의 경우에는 질소와 인의 제거가 동시에 일어난 것으로 보아 struvite 생성으로 인한 알칼리도의 감소

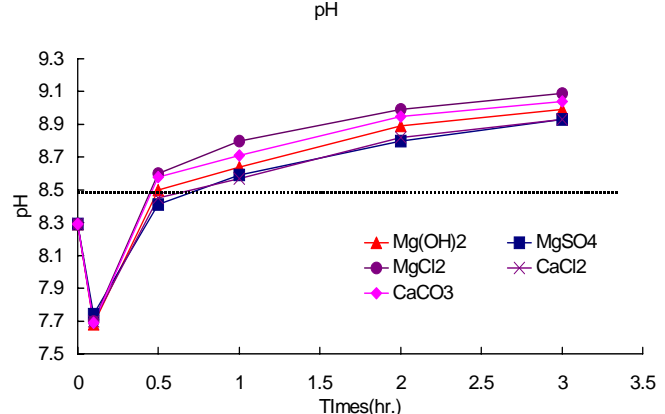

(a) $\mathrm{pH}$ change

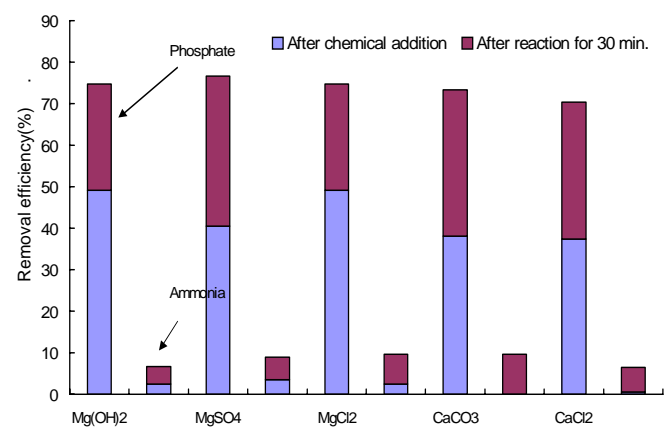

(b) N,P removal efficiencies

Fig. 2. $\mathrm{pH}$ change \& $\mathrm{N}, \mathrm{P}$ removal efficiencies vs chemical source.

라 판단되고 칼슘원의 경우에서는 암모니아 의 제거 없이 인만 제거된 것으로 보아 초기 에 hydroxyapatite(HAP)와 같은 무반응 물질의 형성으로 인해 알칼리도가 소모된 것으로 보여 진다. Struvite와 hydroxyapatite는 결합시 알칼리 도를 소모하는 것으로 보고되고 있으며 시약 주입 직후 마그네슘원이 칼슘원에 비해 암모니 아를 보다 효율적으로 제거하는 것으로 보고되 고 있다(원성연 등, 2000).

포기가 시작됨에 따라 $\mathrm{CO}_{2}$ 의 탈기가 일어나 $\mathrm{pH}$ 는 지속적으로 상승하여 포기 30 분 이내에 결 정화 반응이 활발하게 일어나는 $\mathrm{pH} 8.5$ 수준으로 상승하면서 $\mathrm{Mg}(\mathrm{OH})_{2}, \quad \mathrm{MgSO}_{4}, \mathrm{MgCl}_{2}, \mathrm{CaCO}_{3}$, $\mathrm{CaCl}_{2}$ 각각 $74.7 \%, 76.7 \%, 74.7 \%, 73.3 \%, 70.3 \%$ 의 $\mathrm{PO}_{4}{ }^{3-}$ 의 제거효율과 $6.7 \%, 9.0 \%, 9.7 \%, 9.7 \%$, $6.51 \%$ 의 $\mathrm{NH}_{4}-\mathrm{N}$ 의 제거효율을 보였다. $\mathrm{N}, \mathrm{P}$ 제 거효율을 기준으로 판단할 때 비록 주입원에 
따른 큰 차이는 발견되지 않았으나 struvite의 형성을 유도하기 위한 시약으로 $\mathrm{MgSO}_{4}, \mathrm{MgCl}_{2}$, $\mathrm{CaCO}_{3}$ 을 이용하는 것이 다소 효율적인 것으로 나타났다. 그러나 시험 중 $\mathrm{CaCO}_{3}$ 를 주입원으로 이용할 시에는 $\mathrm{Mg}$ 계통보다 침점물이 많이 생 기고 또한 침전이 불량해지는 현상이 발생함에 따라 시험된 시약들 중 $\mathrm{MgSO}_{4}$ 나 $\mathrm{MgCl}_{2}$ 를 주입 원으로 이용하는 것이 좋을 것으로 판단되었다.

Fig. 3은 공기주입과 교반이 struvite 결정화 반응에 미치는 영향을 알아보기 위하여 $\mathrm{MgSO}_{4}$ 를 인 기준 1.3 몰의 비율로 첨가한 후 $\mathrm{pH}$ 조절 없이 포기와 교반을 하면서 $\mathrm{pH}$ 의 변화와 인 제거양상을 알아본 것이다. 시약 주입 후 $\mathrm{pH}$ 7.5 수준의 용액에 포기를 행한 경우 1 시간만 에 struvite 결정화 반응이 활발하게 일어나는 $\mathrm{pH} 8.5$ 수준 이상으로 상승하면서 $\mathrm{PO}_{4}{ }^{3-}$ 의 제 거효율이 약 $90 \%$ 에 도달한 반면, 교반의 경우 에는 동일 시간동안 $44 \%$ 의 제거효율을 보였으 며 반응 14시간 후에야 $\mathrm{pH} 8.5$ 수준으로 상승하 면서 $90 \%$ 의 $\mathrm{PO}_{4}{ }^{3-}$ 제거를 나타내었다. 이러한 결과로 축산폐수에 struvite 결정화 시약을 주입 한 후 $\mathrm{pH}$ 를 조절하지 않고도 교반과 포기만으 로 결정화 반응을 유도할 수 있음을 알 수 있 었으며 포기방법이 교반에 비해 빠른 $\mathrm{pH}$ 상승 효과를 가져오면서 struvite 결정화 반응을 촉진 함을 알 수 있었다.

포기조건에서 유입폐수의 $\mathrm{pH}$ 에 따른 struvite 결정화 특성을 파악하기 위하여 $\mathrm{NaOH}$ 와 $\mathrm{HCl}$ 을 사용하여 $\mathrm{pH}$ 를 5 11로 조절한 후 $\mathrm{MgSO}_{4}$ 를 인 기준 1.3 몰 비율로 첨가하고 $\mathrm{PO}_{4}^{3-}$ 의 제거

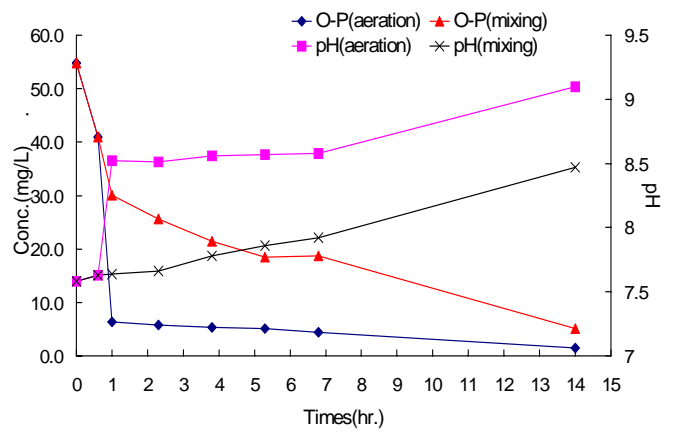

Fig. 3. $\mathrm{pH}$ and $\mathrm{PO}_{4}{ }^{3-}$ under aeration \& mixing condition.

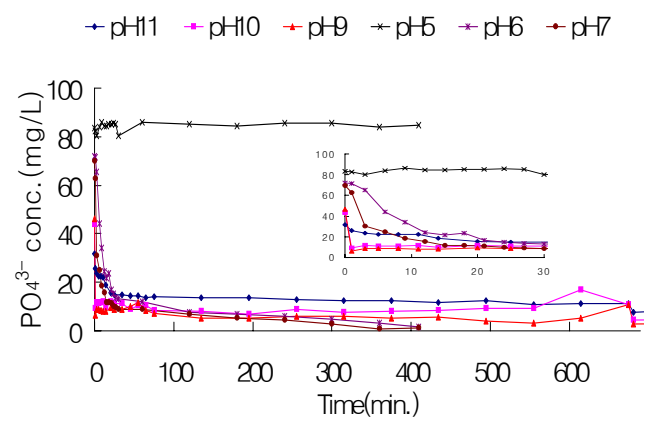

Fig. 4. $\mathrm{PO}_{4}{ }^{3-}$ vs influent $\mathrm{pH}$.

특성을 살펴보았다(Fig. 4). 폐수의 $\mathrm{pH}$ 가 5 수 준일 때는 포기가 이루어짐에도 불구하고 struvite 결정화 반응이 목격되지 않은 반면 $\mathrm{pH}$ $6,7,9$ 일 때는 $\mathrm{pH}$ 의 상승과 struvite 형성이 원 활하여 각각 3 시간, 2 시간, 10 분만에 $90 \%$ 의 $\mathrm{PO}_{4}{ }^{3-}$ 제거효율을 나타냈다. $\mathrm{pH} 10$ 이상에서는 초기 $\mathrm{pH}$ 에 의한 $\mathrm{PO}_{4}{ }^{3-}$ 의 공침 현상이 발생하여 $\mathrm{Mg}$ 원 주입 전에 이미 $50 \%$ 정도의 인이 제거 됨에 따라 실제로 struvite 형성에 의한 인의 제 거량은 많지 않았으며 포기시 과량의 거품이 발생하여 운전에 어려움이 있었다. $\mathrm{pH}$ 11에서 는 오히려 struvite 형성이 둔화되는 결과를 가 져왔다. 이러한 결과로 포기하여 struvite를 생 성하는데 있어서 유입수의 초기 $\mathrm{pH}$ 는 7 9 수 준의 약 알칼리성이 적합할 것으로 여겨지며 축산폐수의 $\mathrm{pH}$ 범위가 대개 이 수준에 있다는 점을 감안할 때 아무런 $\mathrm{pH}$ 조절제 사용 없이 포기만으로 축산폐수내의 질소와 인을 결정화 하여 회수하는 것이 가능하다고 판단된다. 축 산폐수로 부터의 struvite 생성량은 폐수 내 인 의 농도에 따라 달라지는데, 본 연구에 쓰인 폐수의 인의 함량이 약 $87.6 \mathrm{mg} / \mathrm{L}$ 이였으므로 약 $90 \%$ 의 제거를 보일시 $1 \mathrm{~L}$ 의 폐수에서 약 $197 \mathrm{mg}$ 의 struvite를 생산 할 수 있다.

Fig. 5는 축산폐수에 $\mathrm{Mg}$ 원을 첨가하여 생성 되는 struvite 결정체의 현미경적 사진을 나타낸 것이다. Fig. $5 \mathrm{a}$ 는 마그네슘원으로 $\mathrm{MgSO}_{4}$ 을 이 용하여 생성시킨 MAP(Magnesium Ammonium Phosphate) 결정체의 전자현미경 사진이며 $5 \mathrm{~b}$ 는 마그네슘원으로 $\mathrm{MgCl}_{2}$ 를 사용하여 생성된 $\mathrm{MAP}$ 의 400 배에서 형상이다. 축산폐수에서 생 


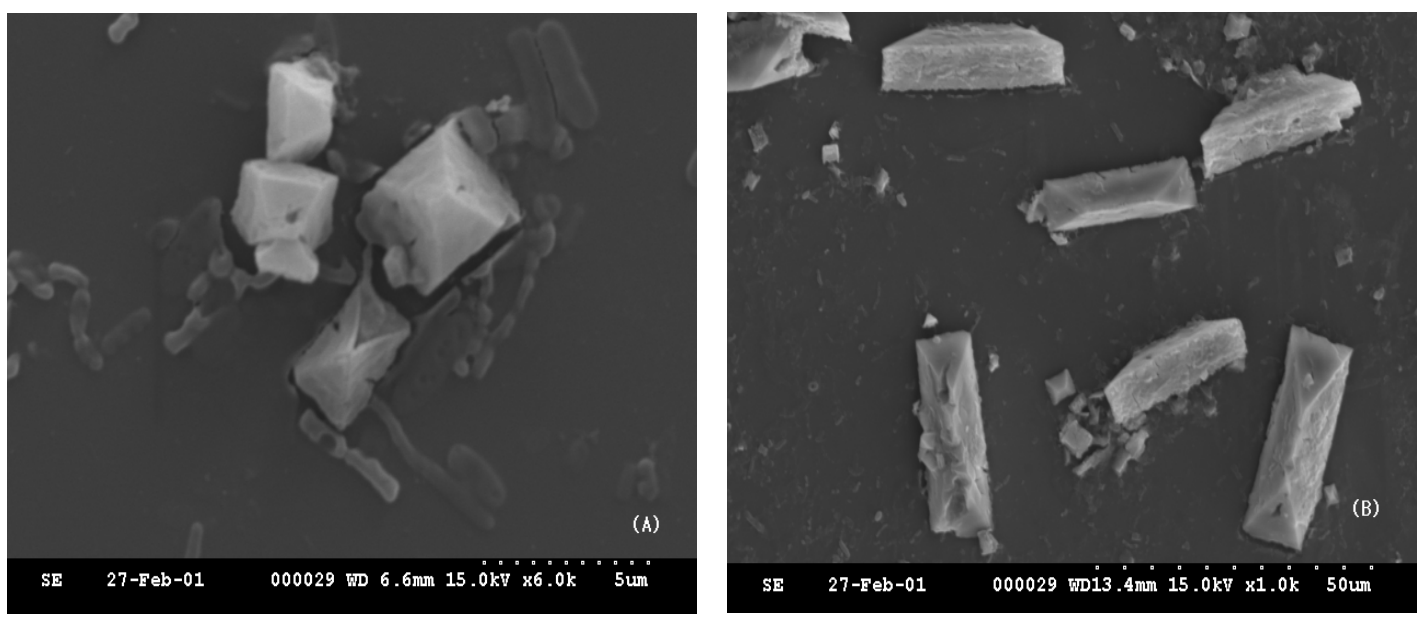

(a) SEM, (A)-6000x, (B)-1000x, chemical source: $\mathrm{MgSO}_{4}$

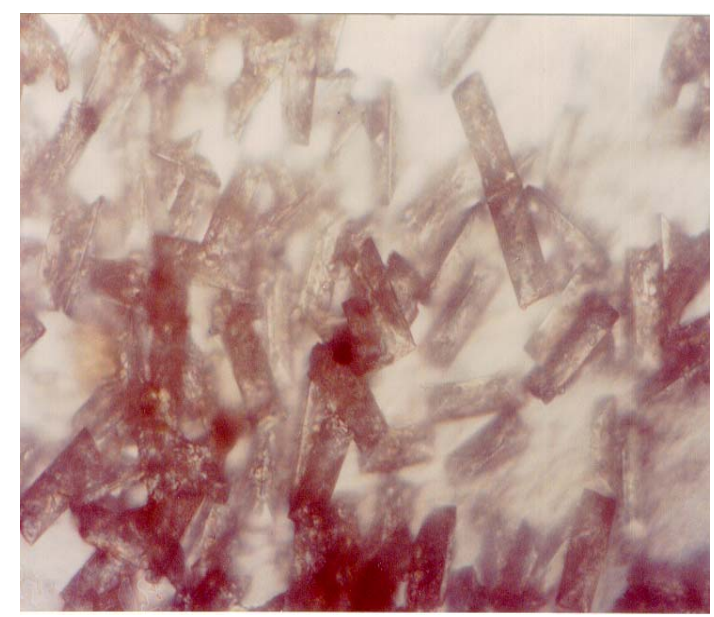

(b) Olympus $\mathrm{AX70}, 400 \mathrm{x}$, chemical source: $\mathrm{MgCl}_{2}$

Fig. 5. Microscopic morphology of struvite.

성되는 MAP 결정체들은 처리가 반복되고 시 간이 경과함에 따라 크기가 점차적으로 증가 하였으며 형성된 구조는 초기에는 밑부분이 정사각형인 피라미드구조(5a-A)를 가지고 있 었으나 struvite 성장에 의해 점차 길어져 밑부 분이 직사각형인(5a-B)와 같은 구조로 변화하 였다. Ueno 등(2001)에 따르면 struvite 결정체 의 크기는 10 일 반응으로 $0.5 \sim 1 \mathrm{~mm}$ 수준까지 도 성장하는 것으로 밝혀지고 있으며 SchulzeRettmer 등 (2001)은 무려 $1 \mathrm{~cm}$ 길이의 crystal 이 분뇨 저장조에서 발견된 적도 있었다고 보고하고 있다.

\section{Struvite와 전기분해법의 연계공정 도출}

축산폐수는 $\mathrm{NH}_{4}-\mathrm{N}$ 과 $\mathrm{PO}_{4}^{3-}$ 의 농도비가 대략 30:1 수준이기 때문에 동일 몰 비로 반응하는 struvite 결정화법에서는 인의 제거효율은 높으 나 암모니아 제거가 부족하고, 불용성 전극을 사용하는 전기분해에서는 반대로 인 제거 효율 은 낮은 반면 암모니아성 질소와 색도의 제거 효율은 높을 것으로 판단되었다. 이에 struvite 결정화법과 전기분해법을 연계하는 최적의 공 정을 도출하고자 Table 2에서와 같은 다양한 연계 공정과 운전방법을 시험하고 그 결과를 


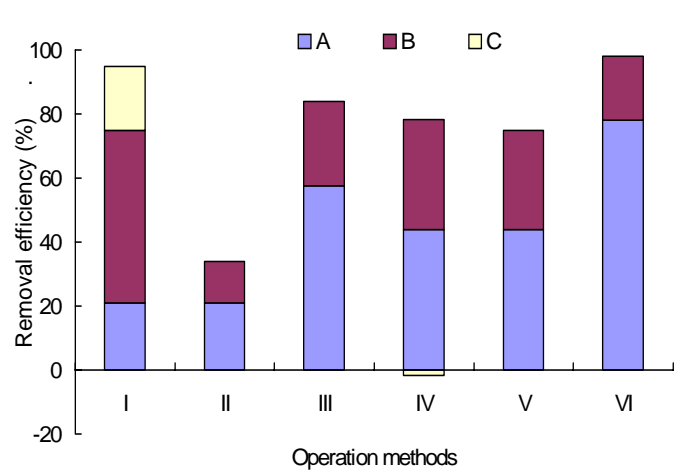

(a) $\mathrm{PO}_{4}{ }^{3-}$ removal efficiency

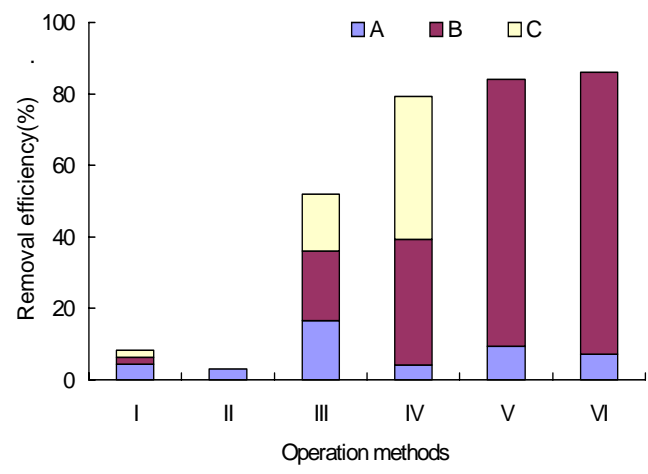

(b) $\mathrm{NH}_{4}^{+}$removal efficiency

I : (A) pH contro $\rightarrow$ B) struvite $\rightarrow$ C) electrolysis,

I : (A) struvite $\rightarrow$ 'B) electrolysis,

III : (A) electrolysis $\rightarrow$ 'B) struvite $\rightarrow$ C) aeration,

IV : (A) struvite $\rightarrow$ B) electrolysis $\rightarrow$ C) aeration,

V : (A) struvite $\rightarrow$ B) electrolysis+aeration,

VI : (A) struvite+aeration $\rightarrow$ B) electrolysis+aeration

Fig. 6. N, P removal vs operation methods.

Fig. 6에 나타내었다. 각 공정에서 struvite 반응 시간은 5 시간, 전기분해는 9 시간으로 동일하게 하였으며 폭기가 따로 수행된 경우에만 별도로 24시간의 폭기시간이 주어졌다.

공정 $\mathrm{I}$ 은 유입수의 $\mathrm{pH}$ 를 9 로 조정한 후 $\mathrm{Mg}$ 원을 첨가하여 MAP 형성을 유도한 다음 상등 수를 전기분해 하는 공정으로서 $\mathrm{pH}$ 조정 후 struvite 반응조에서 $75 \%$ 의 $\mathrm{PO}_{4}{ }^{3-}$ 제거효율과 $6.3 \%$ 의 $\mathrm{NH}_{4}-\mathrm{N}$ 제거효율을 보였으며 전기분해 조에서는 각각 $20 \%$ 와 $1.9 \%$ 의 제거효율을 보여 전체 $95 \%$ 의 인 제거와 $8.2 \%$ 의 암모니아성 질 소의 제거를 얻을 수 있었다. 공정 II는 유입수
의 $\mathrm{pH}$ 조절 없이 $\mathrm{MAP}$ 을 형성시킨 후 상등액 을 전기분해하는 공정으로서 struvite 반응조에 서 $\mathrm{PO}_{4}^{3-} 21 \%, \mathrm{NH} 4-\mathrm{N} 3 \%$ 가 제거되었으며 전 기분해 반응에서 $\mathrm{PO}_{4}^{3-} 21 \%, \mathrm{NH}_{4}-\mathrm{N} 0 \%$ 가 제 거되면서 전체적으로 낮은 제거효율을 보였다. 공정 III은 전기분해 후 $\mathrm{MAP}$ 을 형성시키고 그 상등액을 단순 포기하는 공정으로서 전기분해 에서 인과 암모니아성 질소가 각각 $57.6 \%$, $16.5 \%$, struvite 반응에서 $26.4 \%, 19.5 \%$ 의 제거 를 보였으며 단순포기에서 인의 제거는 없었으 나 암모니아성 질소가 $16 \%$ 제거되어 총 $84 \%$ 의 인과 $54 \%$ 의 암모니아성 질소의 제거효율을 얻 었다. 공정 IV는 struvite 반응 후 상등액을 전 기분해한 다음 포기시키는 공정으로서 struvite 반응에서 인, 암모니아성 질소 각각 $44 \%, 4.2 \%$ 의 제거를 보였으며 전기분해에서는 각각 $34.2 \%, 35 \%$ 의 제거를 보였다. 또한 전기분해 후 공기주입에 의해 인의 감소는 없었으나 암 모니아성 질소는 $40 \%$ 제거되어 총 $76.5 \%$ 의 인 제거와 $79.2 \%$ 의 암모니아성 질소의 제거가 공 정 $\mathrm{IV}$ 에서 얻어졌다. 공정 $\mathrm{V}$ 는 struvite 반응 후 상등액을 포기조건에서 전기분해 시키는 공정 으로 struvite 반응시 인과 암모니아성 질소는 각각 $44 \%$ 와 $9.4 \%$ 의 제거를 보였으며 호기적 전기분해에 의해 인 $31 \%$, 암모니아성 질소 $74.6 \%$ 가 제거되어 총 $75 \%$ 의 $\mathrm{PO}_{4}{ }^{3-}$ 의 제거효율 과 $84 \%$ 의 암모니아성 질소 제거효율을 보였다. 공정 $\mathrm{VI}$ 은 struvite 반응과 전기분해 모두 공기 를 주입하면서 시행하는 공정으로 포기조건의 struvite 반응에 의해 $78 \%$ 의 인 제거 효율과 $7.1 \%$ 의 암모니아성 질소 제거효율을 얻었으며 상등액을 포기시키면서 전기분해 함에 의해 $20 \%$ 의 인 제거와 $78.9 \%$ 의 암모니아성 질소의 제거가 일어나 총 $98 \%$ 의 인 제거와 $86 \%$ 의 암 모니아성 질소제거를 공정 $\mathrm{VI}$ 에서 얻을 수 있 었다. 이러한 결과로 시험된 struvite 결정화 방 법과 전기분해 방법의 연계 공정 중 공정 VI가 돈사폐수에 가장 효율적인 것으로 판단되었다. 참고로 공정 $\mathrm{VI}$ 에서 전기분해에 의한 색도 제 거효율은 92.4\%이었으며 이는 색도 7233 unit를 549 unit로 감소시킨 것이었다.

그러나 struvite를 형성시킨 후 그 상등액을 
전기분해 시키는 공정에서 암모니아성 질소가 산화되면서 $\mathrm{NOx}-\mathrm{N}$ 가 생성되고 또한 염소계통 의 전해물질 첨가 없이는 높은 효율의 $\mathrm{COD}$ 제 거를 얻을 수 없기 때문에 최종 유출수를 농경 지로 관개하거나 혹은 농업용수로 활용하지 않 고 방류하기 위해서는 후처리 공정으로 탈질 공정이 뒤따라야 할 것이며 아울러 전기분해조 에서 유기물질 제거효율을 높이기 위한 운전인 자 등이 파악 - 굥용더야 할 것으로 판단된다. 전기분해조에서 제거된 $\mathrm{NH}_{4}-\mathrm{N}$ 중 $\mathrm{NOx}-\mathrm{N}$ 로 산 화된 양은 $\mathrm{pH}$ 에 따라 다른 것으로 보고되고 있 는데 $\mathrm{pH} 8$ 수준에서 제거된 $\mathrm{NH}_{4}-\mathrm{N}$ 의 약 $7 \%$ 정 도가 $\mathrm{NOx}-\mathrm{N}$ 으로 산화되며 $\mathrm{pH}$ 가 낮을수록 그 양은 증가하는 것으로 보고되고 있다(Vlyssides 등, 2002).

$$
\text { IV 요 약 }
$$

본 연구에서는 축산폐수내에 고농도로 함유 되어 있는 질소와 인을 재생하기 위한 공정으 로서의 struvite 결정화 방법의 운전인자를 파악 하고 폐수처리 측면에서 효율적인 struvite법과 전기분해법과의 연계공정을 도출하고자 하였 다. 유효용적인 2L인 Struvite 반응조를 이용하 여 주입원의 종류, $\mathrm{pH}$, 교반과 폭기 등에 따른 암모니아와 인의 결정화 특성을 파악하였으며, 효율적인 전기분해법과의 연계방법을 찾고자 6 가지 서로 다른 방법에서의 $\mathrm{NH}_{4}-\mathrm{N}$ 과 $\mathrm{PO}_{4}{ }^{3-}$ 의 제거특성을 분석하였다. 시험결과 struvite 형성 을 위한 주입원으로는 $\mathrm{CaCO}_{3}$ 나 $\mathrm{CaCl}_{2}$ 보다는 $\mathrm{MgSO}_{4}$ 혹은 $\mathrm{MgCl}_{2}$ 을 사용하는 것이 효율적인 것으로 판단되었다. 공기주입과 교반이 struvite 결정화 반응에 미치는 영향을 파악한 시험에서 는 포기의 경우 $\mathrm{pH}$ 가 8.5 이상으로 상승하면서 인 제거효율이 $90 \%$ 에 도달하는데 1 시간이 걸 린 반면 교반의 경우에는 14 시간이 걸리는 것 으로 나타나 포기가 교반보다 빠른 $\mathrm{pH}$ 상승효 과를 가져오면서 struvite 결정화 반응을 촉진함 을 알 수 있었다. 포기조건에서의 struvite 결정 화는 유입폐수의 $\mathrm{pH}$ 에 영향을 받는 것으로 나 타났는데 유입폐수의 $\mathrm{pH}$ 가 5수준일 때는 아무 런 결정화가 이루어지지 않았으며 $\mathrm{pH} 6,7,9$
에서는 struvite 결정화가 활발하여 각각 3 시간, 2 시간, 10 분만에 $90 \%$ 의 $\mathrm{PO}_{4}{ }^{3-}$ 가 struvite 반응으 로 제거되었다. 그러나 $\mathrm{pH} 10$ 이상에서는 과량 의 거품발생으로 인한 운전의 어려움이 목격되 었으며 $\mathrm{pH}$ 11에서는 struvite 결정화 반응이 둔 화되는 것으로 나타났다. 이상의 결과와 축산 폐수의 $\mathrm{pH}$ 의 범위가 7 9 수준임을 감안할 때 축산폐수의 경우에는 아무런 $\mathrm{pH}$ 조절제를 사 용하지 않고도 포기만으로도 효율적인 결정화 반응 유도가 가능함을 알 수 있었다. 전기분해 법을 struvite 반응과 연계하여 폐수내 인과 질 소 제거효율을 높이기 위해서는 struvite 결정화 반응과 전기분해를 모두 포기 조건에서 수행하 면서 struvite 반응 후에 상등액을 전기분해 하 는 것이 시험된 공정 중 가장 효율적인 것으로 나타났다. 본 공정에서의 인과 암모니아성 질 소의 제거 효율은 각각 $98 \%$ 와 $86 \%$ 이었으며 색 도 제거효율은 $92.4 \%$ 이었다.

\section{$\mathrm{V}$ 인 용 문 헌}

1. Chang, Li-Choung., Chang, Juu-En. and Wen, TenChen. 1995. Indirect oxidation effect in electrochemical oxidation treatment of landfill leachate. Water research 29(2):671-678.

2. Daumer, M. L., Beline, F., Guiziou, F. and Martinez, J. 2001. Phosphorus recovery following biological aerobic treatment of pig slurry, Second international conference on the recovery of phosphorus from sewage and animal wastes, Holland, 12 13 March.

3. Doyle, James D. and Parsons, Simon A. 2002. Struvite formation, control and recovery, Water research, 36(16):3925-3940.

4. Frank, B. and Mark, L. 2001. Sewage treatment and methods for phosphate recovery in BCFS ${ }^{\circledR}$ processes, Second international conference on the recovery of phosphorus from sewage and animal wastes, Holland, 12 13 March.

5. Jaffer, Y., Clark, T. A., Pearce, P. and Parsons, S. A. 2001. Assessing the potential of full scale phosphorus recovery by struvite formation, Second inter-national conference on the recovery of phosphorus from sewage and animal wastes, Holland, 12 13 March.

6. Karlsson, I. 2001. Full scale plant recovering iron 
phosphate from sewage at Helsingborg sweden, Second international conference on the recovery of phosphorus from sewage and animal wastes, Holland, 12 13 March.

7. Lin, S. H. and WU, C. L. 1996, Electrochemical removal of nitrate and ammonia for aquaculture, Water research 30(3):715-721.

8. Moriyama, K., Kojima, T., Minawa, Y., Matsumoto, S. and Nakamachi, K. 2001. Development of artificial seed crystal for crystallization of calcium phosphate, Second international conference on the recovery of phosphorus from sewage and animal wastes, Holland, 12 13 March.

9. Paul, M., Laval, L. and Sperandio, M. 2001. Excess sludge production and costs due to phosphorus removal, Second international conference on the recovery of phosphorus from sewage and animal wastes, Holland, 12 13 March.

10. Schulze-Rettmer, R., Metzen, P., Alfter, A. and Simbach, B. 2001. MAP precipitation for recovering nutrients from manure, Second international conference on the recovery of phosphorus from sewage and animal wastes, Holland, 12 13 March.

11. Ueno, Y. and Fujii, M. 2001. 3 years operating selling recovered struvite from full-scale plant, Second international conference on the recovery of phosphorus from sewage and animal wastes, Holland, 12 13 March.

12. Vlyssides, A. G., Karlis, P. K., Rori, N. and Zorpas, A. A. 2002. Electrochemical treatment in relation to
$\mathrm{pH}$ of domestic wastewater using $\mathrm{Ti} / \mathrm{Pt}$ electrodes, J. Hazardous materials, B95:215-226.

13. Willem, S., Bram, K., Berend, P., Wim, R., Hardy, T., Ferdinand, K. and Lijmbach, L. 2001. Phosphate recycling in the phosphorus industry, Second international conference on the recovery of phosphorus from sewage and animal wastes, Holland, 12 13 March.

14. 길대수, 이병헌, 이제근, 2000 , 전기분해에 의한 고농도 유기물질 제거 특성, 대한환경공학회지, 22(2):251-264.

15. 김만수, 류홍덕, 이상일, 2002, 침출수의 Struvite 결정화시 결정원의 주입순서가 미치는 영향, 대 한환경공학회지, 24(2):269-275.

16. 원성연, 박승국, 이상일, 2000 , Struvite 결정화에 의한 질소 및 인 제거, 대한환경공학회지, 22(4): 599-607.

17. 이원희. 2000. Struvite(MAP) 결정화 방법을 이용 한 고농도 질소 제거 방안에 관한 연구, 강원대 학교 공학석사학위 논문.

18. 임찬섭, 박정호, 신남철, 2000 , Struvite 형성에 의 한 분뇨의 암모니아성 질소 제거, 한국폐기물학 회지, 17(8):986-993.

19. 조주식, 안명섭, 이홍재, 허재선, 손보균, 허종수, 2000, 전기화학적 방법을 이용한 산업폐수 처리, 한국환경농학회지, 19(2):134-141.

20. 진은정, 길대수, 이창근, 이병헌, 2000. 전기분해 를 이용한 축산폐수의 처리, 한국수처리기술위원 회, 4:29-36.

(접수일자 : 2003. 5. 19. / 채택일자 : 2003. 10. 1.) 